\title{
An isotopic assessment of the feeding habits of free-ranging manatees
}

\author{
Kimberly J. Reich ${ }^{1,2, *}$, Graham A. J. Worthy ${ }^{1,3}$ \\ ${ }^{1}$ Physiological Ecology and Bioenergetics Lab, Department of Marine Biology, Texas A\&M University at Galveston, \\ 4700 Avenue U, Galveston, Texas 77551, USA \\ ${ }^{2}$ Present address: Archie Carr Center for Sea Turtle Research, Department of Zoology, University of Florida, Box 118525, \\ Gainesville, Florida 32611-8525, USA \\ ${ }^{3}$ Present address: Physiological Ecology and Bioenergetics Lab, Department of Biology, University of Central Florida, \\ 4000 Central Florida Blvd., Orlando, Florida 32816-2368, USA
}

\begin{abstract}
There is relatively little information available on how the relative importance of fresh, brackish, or marine environments may vary geographically or individually with respect to manatee Trichechus manatus latirostris feeding ecology. As a first application of stable isotope analysis to determine diet composition of wild manatees, skin from 25 manatee carcasses and leaf tissue from 25 plant species were collected from 4 regions in Florida and analyzed for relative values of stable carbon $\left(\delta^{13} \mathrm{C}\right)$ and nitrogen $\left(\delta^{15} \mathrm{~N}\right)$ isotopes. Values of $\delta^{13} \mathrm{C}$ and $\delta^{15} \mathrm{~N}$ measured in plants ranged from $-0.8 \pm 1.0$ to $6.4 \pm 0.0 \%$ and in manatee tissues from $-8.7 \pm 0.2$ to $-28.3 \pm 0.1 \%$, respectively. A mixing model was applied to estimate manatee diet composition across different geographic regions, and results (mean, all manatees, all regions) indicated that, overall, Florida manatees consumed $44 \%$ of their diet from marine and/or estuarine sources. Manatees living along the central east coast obtained $100 \%$ of their diet from marine and/or estuarine sources, while animals recovered from the St. John's River system (NE region) obtained $\sim 50 \%$ of their diet from freshwater sources, suggesting that some time had been spent outside of the river basin. In conclusion, results of the stable isotope analysis suggest that, even though manatees have a physiological requirement to ingest fresh water, marine and estuarine environments supply a significant fraction of their food resources.
\end{abstract}

KEY WORDS: Manatee $\cdot$ Isotope $\cdot$ Foraging $\cdot$ Aquatic plants $\cdot$ Seagrass

Resale or republication not permitted without written consent of the publisher

\section{INTRODUCTION}

The Florida subspecies of manatee Trichechus manatus latirostris inhabits freshwater rivers and coastal areas in Florida, Georgia, and seasonally may be found as far west as coastal Texas on the Gulf coast and as far north as the Carolinas on the Atlantic coast. Manatees in Florida are known to forage on a wide variety of aquatic vegetation, including freshwater, estuarine, and marine plant species (e.g. Hartman 1979, Best 1981). Distribution of manatees is influenced by a number of factors, including availability of freshwater, winter access to warm water, vegetation on which to feed, and access to waterways of at least $2 \mathrm{~m}$ depth (Hart- man 1979). Studies of migratory patterns indicate that most manatees in Florida move north along the Atlantic coast or west along the Gulf coast in the spring and retreat to Florida in the autumn and winter, many traveling long distances when making these annual migrations (e.g. Lefebvre et al. 1989, Reid et al. 1991, 1995, Ackerman et al. 1995, Deutsch et al. 2000).

As a member of the strictly herbivorous order Sirenia, the Florida manatee is one of a limited number of aquatic megaherbivores and one of the few totally herbivorous marine mammals. In one of the pioneer studies of manatee foraging ecology, Hartman (1979) observed that manatees at Crystal River, Florida, fed almost exclusively on submerged vegetation. Mana- 
tees have also been reported to feed on detritus, overhanging vegetation, bank growth, algae, and acorns (e.g. Hartman 1979, Bengston 1981, O'Shea 1986). Incidental ingestion of insect larvae, amphipods, mollusks, shrimps, and other macroinvertebrates that live in vegetation has also been reported (e.g. Hartman 1971), although in some cases these may be intentionally ingested (Courbis \& Worthy 2003), and it has been hypothesized that these organisms could contribute substantially to the manatee's protein consumption (Hartman 1979).

Historically, studying the feeding ecology of manatees has been accomplished through direct observation, analyzing feces of living manatees, or through stomach content or fecal analysis of recently deceased animals. Gut-content analysis is a procedure that is frequently used to assess diet composition. This method requires sampling material collected from different portions of the digestive tract and usually requires the animal to be sacrificed (e.g. Ledder 1986). Ledder (1986) examined gut contents of 84 manatee carcasses recovered from different regions of Florida; 23 species of plants were found in their digestive tracts, but $77 \%$ of the vegetation was attributed to only 8 species of plants. While analysis of gut content can be useful, this approach only identifies recently consumed materials.

Fecal analysis can also provide insights into foods consumed over a period of several days. Since gut passage time for a manatee is approximately $7 \mathrm{~d}$ (Lanyon \& Marsh 1995), this approach would indicate feeding habits from a short period of time, $7 \mathrm{~d}$ ago. Unlike stomach or gut content analysis, fecal analysis provides a mechanism to examine dietary preferences of living manatees; however, collecting feces in the wild can be problematic. In the absence of alternative tools, fecal analysis is the only method that can provide useful information about foraging habits in free-living manatees.

These approaches all provide information on recent feeding events, but none provides an effective method to assess feeding habits over a longer period of time. Previous studies, on a wide variety of species, have shown that naturally occurring stable isotopes can be used as an effective method to study ecosystem dynamics. Using differences in ratios of the stable isotopes of carbon $\left({ }^{13} \mathrm{C} /{ }^{12} \mathrm{C}\right)$ and nitrogen $\left({ }^{15} \mathrm{~N} /{ }^{14} \mathrm{~N}\right)$ between dietary sources and predator tissues allows the source of the diet to be traced and the trophic level of an animal determined (e.g. Peterson \& Fry 1987). Because of the relative difficulty in undertaking observational studies and the potential limitations of ingesta and fecal analysis, stable isotope analysis may provide the best way to look at long- and short-term feeding habits and to facilitate quantitative analyses of manatee feeding habits.
Due to changes in the relative abundance of isotopes (fractionation) that occur as a result of chemical, biological, and physical processes, isotope ratios vary predictably along a number of environmental gradients. These ratios are incorporated into the tissues of organisms inhabiting these regions as they assimilate nutrients from their environment. As a result, different biological materials or similar materials from different locations generally have distinct 'isotopic signatures' (e.g. DeNiro \& Epstein 1978, Gannes et al. 1998). With these natural abundance variations as tracers, stable isotope analysis has been used successfully in dietary analyses of terrestrial (e.g. DeNiro \& Epstein 1978, Teeri \& Schoeller 1979, Tieszen et al. 1983) and marine food webs (e.g. Fry \& Arnold 1982, Hobson \& Welch 1992, Hobson \& Schell 1998), but they have not previously been used to investigate dietary preferences of any species of herbivorous marine mammals.

Analysis of $\delta^{13} \mathrm{C}$ values in manatee tissue could provide a way to examine manatee food sources by habitat type and geographic region. Given the extensive range and diversity of habitats encountered by manatees, it is reasonable to expect that the foraging habits of individual manatees may vary regionally. We attempted to assess the effectiveness of stable isotope analysis to determine diet composition of wild manatees by analyzing plants commonly consumed by manatees from 4 regions in Florida. Values of carbon $\left(\delta^{13} \mathrm{C}\right)$ and nitrogen $\left(\delta^{15} \mathrm{~N}\right)$ from the plants were compared to carbon and nitrogen values of epidermal, dermal, and muscle tissue from manatee carcasses recovered in the same regions, in order to determine the relative importance of freshwater, estuarine, and marine plant species for the Florida manatee.

\section{MATERIALS AND METHODS}

Skin samples of manatee Trichechus manatus latirostris were obtained from the Marine Mammal Pathobiology Lab, Fish and Wildlife Research Institute, St. Petersburg, Florida, USA, and from SeaWorld of Florida, Orlando. Samples were assigned to geographic regions based on their collection site. For purposes of the present study, the west coast was treated as both 2 separate regions (northwest [NW], including Tampa Bay, and southwest [SW], from south of Tampa Bay to Florida Bay) and as a single region; the east coast was divided at latitude $27.5^{\circ} \mathrm{N}$ into the central east (CE) and southeast (SE) regions, and the St. Johns River was designated as the northeast (NE) region. Selection of specific animals was determined by establishing selection parameters, such as a minimum age category of sub-adults (Ackerman et al. 1995) and only using animals whose necropsy results did not indicate long-term illness or starvation. 
Samples of aquatic plant species, known to be consumed by manatees, were collected from freshwater, estuarine, and marine habitats, in the same areas in which carcasses were collected; they were then frozen until preparation and analysis.

Tissue samples and plant preparation. Skin samples were taken from the ventral sides of manatees $(n=25)$, anterior to the umbilicus, and they were frozen at $-20^{\circ} \mathrm{C}$ until the time of analysis. After thawing, subsamples of epidermal and dermal tissue (approximately $50 \mathrm{mg}$ wet weight) were excised, rinsed in distilled water, and further processed for analysis. Skin and plant samples were dried to constant mass in a lyophilizer (Labconco) for a period of 24 to $36 \mathrm{~h}$. After drying, skin was finely diced and homogenized using a scalpel. Because of the variability of lipid content and because lipids are known to be depleted in $\delta^{13} \mathrm{C}$, all tissue and plant samples were run through a Soxhlet extractor (using petroleum ether as the solvent) for $24 \mathrm{~h}$ to remove lipids. Samples were then oven dried at $60^{\circ} \mathrm{C}$ for $24 \mathrm{~h}$ to evaporate any remaining solvent. Then, 1.0 to $1.9 \mathrm{mg}$ of sample was sealed into a $4.5 \times$ $6 \mathrm{~mm}$ tin capsule and analyzed for $\delta^{13} \mathrm{C}$ and $\delta^{15} \mathrm{~N}$ using a mass spectrometer (see below).

Isotope analysis. Preliminary samples were analyzed using a Finnigan Delta S continuous isotope ratio mass spectrometer at the Rangeland Ecology and Management Laboratory, Texas A\&M University, College Station, Texas. The remaining samples were analyzed in the Analytical Chemistry Laboratory, Institute of Ecology, University of Georgia, using a Finnigan Delta mass spectrometer coupled to a Carlo Erba CHN, NA 1500 Series, combustion analyzer via a Finnigan Conflo II interface.

Relative abundance of stable isotopes is normally recorded in $\delta$ notation (\%) according to the following:

$$
\delta X=\left[\left(R_{\text {sample }} / R_{\text {standard }}\right)-1\right] \times 1000
$$

where $X$ is ${ }^{15} \mathrm{~N}$ or ${ }^{13} \mathrm{C}$ and $R$ is the corresponding ratio ${ }^{15} \mathrm{~N} /{ }^{14} \mathrm{~N}$ or ${ }^{13} \mathrm{C} /{ }^{12} \mathrm{C} ; R_{\text {standard }}$ for $\delta^{15} \mathrm{~N}$ is atmospheric $\mathrm{N}_{2}$ and for $\delta^{13} \mathrm{C}$ is PeeDee Belemnite (PDB, carbonate from the fossil skeleton of Belemnitella americana from the PeeDee formation of South Carolina).

Statistical analysis was performed using $t$-tests to compare values of vegetation species collected from $>1$ location. Samples were grouped into categories, based on habitat, for the purpose of determining a mean value per group and region. Three primary categories were used to group vegetation: freshwater, estuarine, and marine. Between-group differences were examined using ANOVA.

Isotopic model. A dual isotope, 3 source $(A, B$, and C) mixing model, formulated from the following mass balance equations, was used (Phillips \& Gregg 2001):

$$
\begin{gathered}
\bar{\delta}_{\mathrm{m}-1}=f_{A} \cdot \bar{\delta}_{A}+f_{B} \cdot \bar{\delta}_{B}+f_{C} \cdot \bar{\delta}_{C} \\
\bar{\lambda}_{\mathrm{m}-3}=f_{A} \cdot \bar{\lambda}_{A}+f_{B} \cdot \bar{\lambda}_{B}+f_{C} \cdot \bar{\lambda}_{C} \\
1=f_{A}+f_{B}+f_{C}
\end{gathered}
$$

where $\delta$ is ${ }^{13} \mathrm{C}$ and $\lambda$ is ${ }^{15} \mathrm{~N}, f$ is the approximate percentage contribution to total diet, the Subscript $m$ indicates manatee tissue, and $\mathrm{A}, \mathrm{B}$, and $\mathrm{C}$ refer to plants found in freshwater, estuarine, or marine environments, respectively. Vegetation endpoints were corrected for isotopic fractionation before being used in the mixing model. An Excel spreadsheet was used to perform calculations for source proportions and their variances, standard errors, and 95\% confidence intervals (Phillips \& Gregg 2001).

The standard accepted stepwise enrichment from prey to predator for marine systems for $\delta^{13} \mathrm{C}$ is $\sim 1$ to $3 \%$ and for $\delta^{15} \mathrm{~N}$ is $\sim 3$ to $5 \%$ o (Schoeninger \& DeNiro 1984, Hobson \& Welch 1992). The model of Phillips \& Gregg (2001) requires that the 'corrected' isotopic values of the consumer fall within a polygon outlined by the potential food sources. In order to achieve results that fell within the polygon, diet-tissue enrichment values for all animals were assumed to be $+3 \%$ for $\delta^{13} \mathrm{C}$ and $+5 \%$ for $\delta^{15} \mathrm{~N}$. These proposed enrichment values fall within the accepted range for mammals in general, as well as for manatees specifically (Ames et al. 1996, Alves \& Worthy unpubl. data). Due to limited sample size, as well as the sensitivity of the linear mixing model to out-of-bound values, the results of the model should be considered a general index of assimilated diet composition rather than a precise estimate of manatee dietary composition (Ben-David \& Schell 2001).

\section{RESULTS}

\section{Plant isotope analysis}

Mean $\delta^{13} \mathrm{C}$ values ranged from $-8.8 \pm 0.4$ to $-28.3 \pm$ $0.2 \%$, while $\delta^{15} \mathrm{~N}$ ranged from $-0.8 \pm 1.0$ to $6.4 \pm 0.0 \%$ o (Table 1). There were, however, no significant differences in isotopic values for plant species in a given habitat within a single region (Table 1, Fig. 1). Seagrasses and mangroves in the SE region, although carrying a similar $\delta^{15} \mathrm{~N}$ signature $(1.4$ and $1.5 \%$, respectively) were easily distinguished by $\delta^{13} \mathrm{C}$ values $(-11.2$ and $-26.9 \%$; Table 1, Fig. 1). Freshwater and estuarine vegetation in the $\mathrm{NE}$ region had similar $\delta^{15} \mathrm{~N}$ values of $5.4 \pm 0.33$ and $4.7 \pm 0.50 \%$, respectively, while average $\delta^{15} \mathrm{~N}$ values for seagrasses were $1.7 \pm 0.24 \%$. Despite these similarities, the 3 potential habitat sources could be identified by $\delta^{13} \mathrm{C}$ values (marine: $-13.0 \pm 1.13 \%$; estuarine: $-18.1 \pm 0.72 \%$; and freshwater: $-28.0 \pm$ 
Table 1. Mean values of $\delta^{15} \mathrm{~N}$ and $\delta^{13} \mathrm{C} \pm \mathrm{SD}$ of plant species analyzed in the present study. Superscripts refer to Fig. 1

\begin{tabular}{|c|c|c|c|c|}
\hline Sample description & $\mathrm{n}$ & Region & Mean $\delta^{15} \mathrm{~N}(\%$ ) & Mean $\delta^{13} \mathrm{C}(\%)$ \\
\hline Enteromorpha ${ }^{\mathrm{c}}$ & 3 & Southwest/Tampa Bay & $0.1 \pm 0.3$ & $-11.4 \pm 0.0$ \\
\hline Mangrove $^{\mathrm{a}}$ & 7 & Southwest/Tampa Bay & $2.0 \pm 1.7$ & $-26.9 \pm 0.1$ \\
\hline Spartina alterniflora $^{\mathrm{b}}$ & 3 & Southwest/Tampa Bay & $3.7 \pm 2.5$ & $-13.6 \pm 0.2$ \\
\hline Thalassia testudinum ${ }^{\mathrm{c}}$ & 3 & Southwest/Tampa Bay & $1.4 \pm 1.2$ & $-9.6 \pm 1.2$ \\
\hline Syringodium filiforme ${ }^{\mathrm{c}}$ & 3 & Southwest/Tampa Bay & $0.3 \pm 1.0$ & $-8.8 \pm 0.4$ \\
\hline Halodule wrightiic & 6 & Southwest/Tampa Bay & $-0.8 \pm 1.0$ & $-10.8 \pm 0.2$ \\
\hline Ceratophyllum demersum ${ }^{\mathrm{a}}$ & 3 & Northwest/Crystal River & $-0.7 \pm 0.4$ & $-24.3 \pm 0.1$ \\
\hline Potomageten sp. ${ }^{\mathrm{b}}$ & 3 & Northwest/Crystal River & $-1.2 \pm 0.2$ & $-19.4 \pm 0.7$ \\
\hline Eichornia crassipes ${ }^{\mathrm{a}}$ & 3 & Northwest/Crystal River & $4.1 \pm 0.3$ & $-23.6 \pm 4.0$ \\
\hline Vallisneria americana ${ }^{\mathrm{b}}$ & 3 & Northwest/Crystal River & $4.7 \pm 0.1$ & $-18.1 \pm 0.0$ \\
\hline Myriophyllum sp. ${ }^{\mathrm{b}}$ & 3 & Northwest/Crystal River & $3.8 \pm 0.1$ & $-21.2 \pm 0.2$ \\
\hline Pistia stratiotes ${ }^{\mathrm{a}}$ & 3 & Northwest/Crystal River & $3.9 \pm 0.3$ & $-27.9 \pm 0.1$ \\
\hline Hydrilla verticillata $^{\mathrm{b}}$ & 3 & Northwest/Crystal River & $2.4 \pm 0.3$ & $-21.7 \pm 0.1$ \\
\hline Unidentified algae $^{\mathrm{a}}$ & 3 & Northwest/Homosassa River & $4.6 \pm 0.2$ & $-26.6 \pm 0.4$ \\
\hline Najas guadalupensis ${ }^{\mathrm{a}}$ & 3 & Northwest/Homosassa River & $5.5 \pm 0.3$ & $-27.3 \pm 0.1$ \\
\hline Spicatum $^{a}$ & 3 & Northwest/Homosassa River & $5.9 \pm 0.1$ & $-24.1 \pm 0.1$ \\
\hline Typha sp. ${ }^{a}$ & 3 & Northwest/Homosassa River & $4.0 \pm 0.3$ & $-27.5 \pm 0.1$ \\
\hline Panicum sp. ${ }^{\mathrm{a}}$ & 3 & Northwest/Homosassa River & $6.4 \pm 0.0$ & $-26.0 \pm 0.2$ \\
\hline Unidentified grass $^{\mathrm{a}}$ & 3 & Northeast/Blue Springs & $6.3 \pm 0.1$ & $-28.3 \pm 0.2$ \\
\hline Eichornia crassipes ${ }^{\mathrm{a}}$ & 3 & Northeast/Blue Springs & $5.9 \pm 0.1$ & $-29.0 \pm 0.1$ \\
\hline Pistia stratiotes ${ }^{\mathrm{a}}$ & 3 & Northeast/Blue Springs & $4.1 \pm 0.1$ & $-26.6 \pm 0.3$ \\
\hline Halodule wrightii $^{\mathrm{b}}$ & 3 & Northeast/Banana River & $2.7 \pm 0.2$ & $-16.5 \pm 0.4$ \\
\hline Ruppia maritima ${ }^{\mathrm{b}}$ & 2 & Northeast/Banana River & $1.4 \pm 0.1$ & $-13.8 \pm 0.2$ \\
\hline Syringodium filiforme $\mathrm{c}^{\mathrm{c}}$ & 3 & Northeast/Banana River & $1.1 \pm 0.2$ & $-8.8 \pm 0.2$ \\
\hline Caulerpa ${ }^{\mathrm{b}}$ & 3 & Northeast/Banana River & $6.1 \pm 0.2$ & $-14.8 \pm 0.2$ \\
\hline Mangrove $^{\mathrm{a}}$ & 3 & Southeast/Palm Beach County & $1.5 \pm 0.3$ & $-26.9 \pm 0.2$ \\
\hline Spartina alterniflora ${ }^{\mathrm{b}}$ & 3 & Southeast/Palm Beach County & $3.5 \pm 0.6$ & $-13.4 \pm 0.2$ \\
\hline Thalassia testudinum ${ }^{\mathrm{c}}$ & 3 & Southeast/Palm Beach County & $1.2 \pm 0.2$ & $-10.8 \pm 0.8$ \\
\hline Syringodium filiforme $\mathrm{c}^{\mathrm{c}}$ & 3 & Southeast/Palm Beach County & $1.1 \pm 0.2$ & $-8.7 \pm 0.2$ \\
\hline Halodule wrightii ${ }^{\mathrm{b}}$ & 3 & Southeast/Palm Beach County & $2.0 \pm 0.3$ & $-14.1 \pm 1.3$ \\
\hline
\end{tabular}

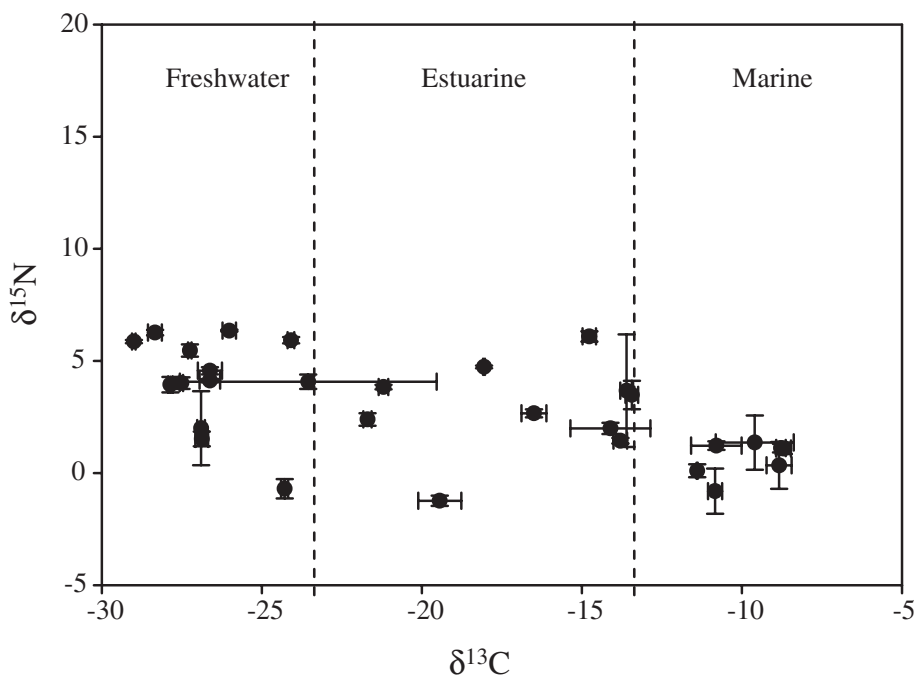

Fig. 1. Average stable nitrogen and carbon isotope values $( \pm$ SD) of plants collected in Florida waters of varying salinities and analyzed in the present study. Each species is identified and mean values are presented in Table 1
$0.36 \%$ ). In the SW region, freshwater and estuarine vegetation had average $\delta^{15} \mathrm{~N}$ signatures of $2.0 \pm 0.92$ and $3.7 \pm 1.44 \%$, respectively, while average seagrass values were $0.3 \pm 0.63 \%$ o (Table 1, Fig. 1). Habitat sources in the SW could still be identified by their $\delta^{13} \mathrm{C}$ values (freshwater: $-22.5 \pm 0.05 \%$; estuarine: $-13.6 \pm$ $0.19 \%$; and seagrasses: $-9.8 \pm 0.59 \%$ ). Nitrogen isotope values in the NW region were higher in the freshwater Homosassa and Crystal Rivers, and lower for estuarine vegetation. Stable-carbon isotope values were $\delta^{13} \mathrm{C}$ enriched in the estuarine samples $(-19.0 \pm$ $1.93 \%$ ) and depleted in the Homosassa River $(-26.0 \pm$ $0.35 \%$ ) and Crystal River (-22.5 $\pm 0.71 \%$ o).

\section{Tissue isotope analysis}

Isotope values of manatee Trichechus manatus latirostris epidermal layers varied significantly with region. Mean $\delta^{15} \mathrm{~N}$ values ranged from $5.7 \pm 2.1 \%$ o in 




Fig. 2. Trichechus manatus latirostris. Relative value of $\delta^{15} \mathrm{~N}$ and $\delta^{13} \mathrm{C}$ isotopes $( \pm \mathrm{SD})$ for manatee skin from Florida. Manatees are represented, as in Table 2 , by the region in which the sample was collected. CE: central east

manatees from the SW region $(\mathrm{n}=8)$ to $9.6 \pm 0.7 \%$ in animals from the NE region $(\mathrm{n}=2)$ (Table 2, Fig. 2). $\delta^{13} \mathrm{C}$ values ranged from a mean of $-10.2 \pm 1.8 \%$ for animals from the CE region $(\mathrm{n}=6)$ to $-19.2 \pm 4.3 \%$ in animals from the NE (n=2) (Fig. 2). Manatee samples from the NE region ( $\mathrm{n}=2)$ showed the greatest enrichment of $\delta^{15} \mathrm{~N}$, while animals from the SW region $(\mathrm{n}=8)$ showed the least enrichment. Manatees from the CE and SE regions showed the most enriched values of $\delta^{13} \mathrm{C}$, while animals from the $\mathrm{NE}$ region were most depleted in $\delta^{13} \mathrm{C}$.

\section{Mixing models}

When the mixing model was applied, results suggested that manatees recovered from the SE region ( $n=6$ ) obtained $\sim 46 \%$ of their assimilated diet from seagrasses; freshwater vegetation contributed approximately $44 \%$, and estuarine vegetation made up the remaining $\sim 10 \%$ (Table 2 ). Mixing model results for samples from the NE region $(n=2)$ suggested that these manatees relied heavily on freshwater food sources $(\sim 50 \%)$ and estuarine vegetation ( 34\%), with marine vegetation accounting for the remaining $\sim 16 \%$ (Table 2). The 2 manatees collected in the NE region were both recovered from the St. John's River, a freshwater river with a large overwintering manatee population. Mixing model results suggest that manatees from the west coast of Florida (SW and NW combined; $\mathrm{n}=11$ ) derive $\sim 49 \%$ of their assimilated diet from freshwater sources, with seagrasses comprising an additional $\sim 48 \%$ of the source material, and estuarine vegetation accounting for the remaining $\sim 3 \%$ (Table 2$)$. In the $\mathrm{CE}$ region $(\mathrm{n}=6)$, model results suggest that marine sources accounted for $\sim 67 \%$ of their diet (Table 2), with estuarine vegetation accounting for the remainder of their diet. Our results suggest that vegetation from a freshwater habitat was not a component of their diet (Table 2).

\section{DISCUSSION}

The Florida manatee Trichechus manatus latirostris is known to eat a variety of aquatic and semi-aquatic plants (e.g. Hartman 1971, Bengston 1981), as it moves between marine, estuarine, and freshwater environments (Best 1981), but little is known about how the proportions of these food sources vary either on an individual or a regional basis. Feeding generally occurs in shallow water, and submerged vegetation is preferred over natant or emergent vegetation (Hartman 1971, Bengston 1981). Selection of feeding sites seems to be indiscriminant and dependent, to some extent, on availability and access (Hartman 1979). Along with the vegetation, manatees ingest encrusting organisms such as diatoms, algae, mollusks, arthropods, cnidarians, amphipods, and other crustaceans that are abundant on the roots and foliage of both

Table 2. Trichechus manatus latirostris. Isotope means of manatee samples, dermis, epidermis, and sloughed skin composites $( \pm \mathrm{SD})$. Manatee samples are presented by the region of Florida in which the sample was collected

\begin{tabular}{|c|c|c|c|c|c|c|}
\hline Region & $\mathrm{n}$ & $\delta^{15} \mathrm{~N}(\%)$ & $\delta^{13} \mathrm{C}(\%)$ & Marine (\%) & Estuarine (\%) & Freshwater (\%) \\
\hline Southwest & 8 & $5.7 \pm 2.1$ & $-15.0 \pm 3.2$ & 40 & 4 & 56 \\
\hline Northwest & 3 & $6.4 \pm 1.1$ & $-14.6 \pm 5.5$ & 69 & 0 & 31 \\
\hline NW/SW combined & 11 & & & 48 & 3 & 49 \\
\hline Northeast & 2 & $9.6 \pm 0.7$ & $-19.2 \pm 4.3$ & 16 & 34 & 50 \\
\hline Central east & 6 & $7.3 \pm 1.0$ & $-10.2 \pm 1.8$ & 67 & 33 & 0 \\
\hline Southeast & 6 & $7.1 \pm 2.6$ & $-12.1 \pm 3.2$ & 46 & 10 & 44 \\
\hline
\end{tabular}




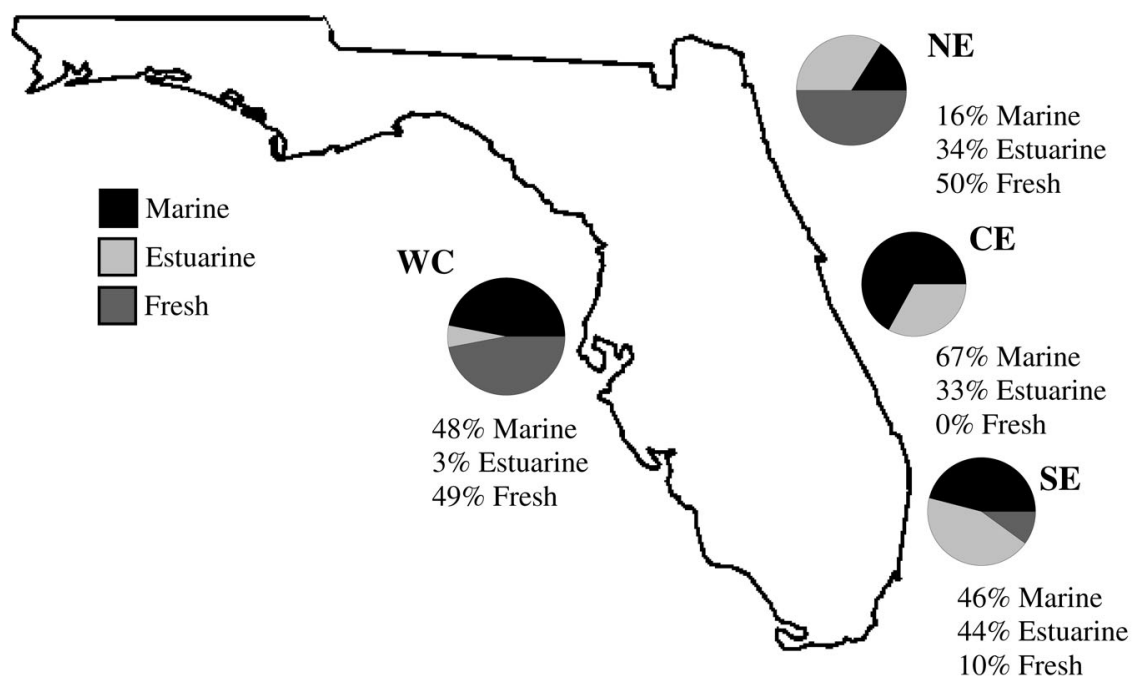

Fig. 3. Trichechus manatus latirostris. Summary of regional feeding preferences of the Florida manatee. WC: west coast; NE: northeast; CE: central east: SE: southeast entirely of marine and estuarine vegetation. Of course, if freshwater food resources are available, manatees will take advantage of them.

Overall, by better understanding short- and long-term feeding strategies, habitat use, and the relative importance of freshwater, estuarine, and marine habitats, we can better identify habitats that are in need of protection. The results of the present study support the use of isotopic techniques to further research on manatee foraging and habitat utilization, and, when used in conjunction with telemetry and observational data, stable isotope data may also be useful in the identification of critical habitats as outlined in the Manatee Recovery Plan. aquatic and natant vegetation (Hartman 1979). The first recorded observation of carnivorous behavior in manatees was documented in Puerto Rico (Powell 1978), where manatees were observed feeding on the flesh of dead fish caught in fishermen's nets.

Isotope analysis has previously been shown to be useful in determining diets of animals that are difficult to observe in the wild (e.g. Peterson \& Fry 1987). Unfortunately, the elemental turnover rates for manatee skin are unknown, and this makes it difficult to assign a time course to observed isotopic values. Recent work (Alves \& Worthy unpubl. data) suggests that the turnover time of manatee dermal tissue is on the order of $45 \mathrm{~d}$.

Results of the present study indicate that there are significant regional differences in foraging strategies amongst manatees, but that, regardless of region, nearly half of all vegetation consumed came from either a marine or an estuarine source (Fig. 3). This ranged from a diet comprised entirely of marine and estuarine vegetation in the $\mathrm{CE}$ region to one comprised of $\sim 47 \%$ marine vegetation on the west coast of Florida. These results suggest that, despite a need for regular access to freshwater for drinking (Ortiz et al. 1998), estuarine and/or marine food sources play a significant role in manatee feeding ecology. In a study of manatee osmoregulation, Ortiz et al. (1998) hypothesized that although manatees that consumed strictly marine vegetation would require regular access to a freshwater source, those having access to estuarine flora may not need an additional source of freshwater. This hypothesis appears to be supported by results of the isotopic analysis of animals recovered in the CE region (Fig. 3), which indicated their diets consisted
Acknowledgements. Funding for this project was provided by Save the Manatee Club and Texas A\&M University. The authors thank FMRI, The Sirenia Project, FDEP, W. Hartley, B. Dearth, B. Bonde and C. Beck for permitting assistance and sample collection. L. Cifuentes, K. A. Hobson and K. O. Winemiller contributed advice and critical insight to the study design and analysis. We also thank S. Kumagai and T. Worthy for lab assistance.

\section{LITERATURE CITED}

Ackerman BB, Wright SD, Bonde RK, Odell DK, Banowetz DJ (1995) Trends and patterns in mortality of manatees in Florida, 1974-1992. In: O'Shea TJ, Ackerman BB, Percival HF (eds) Population biology of the Florida manatee. National Biological Service Information and Technology Report I, USGS Sirenia Project, Gainesville, FL, p 223-258

Ames AL, vanVleet ES, Sackett WM (1996) The use of stable carbon isotope analysis for determining the dietary habits of the Florida manatee, Trichechus manatus latirostris. Mar Mamm Sci 12:555-563

Ben-David M, Schell DM (2001) Mixing models in analyses of diet using multiple stable isotopes: a response. Oecologia 127:180-184

Bengston JL (1981) Ecology of manatees (Trichechus manatus) in the St. Johns River, Florida. PhD dissertation, University of Minnesota, Minneapolis, MN

Best RC (1981) Foods and feeding habits of wild and captive Sirenia. Mamm Rev 11:3-29

Courbis SS, Worthy GAJ (2003) Opportunistic rather than incidental carnivory by Florida manatees (Trichechus manatus latirostris)? Aquat Mamm 29:104-107

DeNiro MJ, Epstein S (1978) Influence of diet on the distribution of carbon isotopes in animals. Geochim Cosmochim Acta 42:495-506

Deutsch CJ, Reid JP, Bonde RK, Easton DE, Kochman HI, Zoodsma BJ (2000) Seasonal movements, migratory behavior, and site fidelity of West Indian manatees along the Atlantic Coast of the United States as determined by radio-telemetry. Final Report Research Work Order 163, 
Florida Cooperative Fish and Wildlife Research Unit, USGS and University of Florida, Gainesville, FL

Fry B, Arnold C (1982) Rapid 13C/12C turnover during growth of brown shrimp (Penaeus aztecus). Oecologia 54: 200-204

Gannes LZ, O'Brien DM, Martinez del Rio C (1998) Stable isotopes in animal ecology: assumptions, caveats, and a call for more laboratory experiments. Ecology 78:1271-1276

Hartman DS (1971) Behavior and ecology of the Florida manatee, Trichechus manatus latirostris (Harlan), at Crystal River, Citrus County. PhD dissertation, Cornell University, Ithaca, NY

Hartman DS (1979) Ecology and behavior of the manatee (Trichechus manatus) in Florida. Special Publication No. 5, American Society of Mammalogy, Pittsburgh, PA

Hobson KA, Schell DM (1998) Stable carbon and nitrogen isotope patterns in baleen from eastern Arctic bowhead whales (Balaena mysticetus). Can J Fish Aquat Sci 55: 2601-2607

Hobson KA, Welch HE (1992) Determination of trophic relationships within a high Arctic marine food web using $\delta^{13} \mathrm{C}$ and $\delta^{15} \mathrm{~N}$ analysis. Mar Ecol Prog Ser 84:9-18

Lanyon JM, Marsh H (1995) Digesta passage times in the dugong. Aust J Zool 43:119-127

Ledder DA (1986) Food habits of the West Indian manatee, Trichechus manatus latirostris, in South Florida. MS thesis, University of Miami, FL

Lefebvre LW, O'Shea TJ, Rathbun GB, Best RC (1989) Distribution, status and biogeography of the West Indian manatee. Sandhill Crane Press, Gainesville, FL

Editorial responsibility: Howard I. Browman (Associate Editor-in-Chief), Storebø, Norway
Ortiz RM, Worthy GAJ, Mackenzie DS (1998) Osmoregulation in wild and captive West Indian manatees (Trichechus manatus). Physiol Zool 71:449-457

O'Shea TJ (1986) Mast foraging by West Indian manatees (Trichechus manatus). J Mammal 67:183-185

Peterson BJ, Fry B (1987) Stable isotopes in ecosystem studies. Annu Rev Ecol Syst 18:293-320

Phillips DL, Gregg JW (2001) Uncertainty in source partitioning using stable isotopes. Oecologia 127:171-179

Powell JA (1978) Evidence of carnivory in manatees (Trichechus manatus). J Mammal 59:442

Reid JP, Rathbun GA, Wilcox JR (1991) Distribution patterns of individually identifiable West Indian manatees (Trichechus manatus) in Florida. Mar Mamm Sci 7:180-190

Reid JP, Bonde RK, O'Shea TJ (1995) Reproduction and mortality of radio-tagged and recognizable manatees on the Atlantic coast of Florida. In: O'Shea TJ, Ackerman BB, Percival HF (eds) Population biology of the Florida manatee. National Biological Service Information and Technology Report I, NBS, Gainesville, FL, p 171-191

Schoeninger MJ, DeNiro MJ (1984) Nitrogen and carbon isotopic composition of bone collagen from marine and terrestrial animals. Geochim Cosmochim Acta 48:625-639

Teeri JA, Schoeller DA (1979) ${ }^{13} \mathrm{C}$ values of an herbivore and the ratio of $\mathrm{C}_{3}$ to $\mathrm{C}_{4}$ plant carbon in its diet. Oecologia 39: 197-200

Tieszen LL, Boutton TW, Tesdahl KG, Slade NA (1983) Fractionation and turnover of stable carbon isotopes in animal tissues: implications for $\delta^{13} \mathrm{C}$ analysis of diet. Oecologia $57: 32-37$

Submitted: June 10, 2005; Accepted: February 23, 2006

Proofs received from author(s): August 29, 2006 